\title{
Retrospective Study on Epidemiology of Infectious Bursal Disease in Broiler Chickens in Haryana, India
}

\author{
Pooja Kundu* , G. Narang, N.K. Mahajan, Priyanka Yadav and N. Jindal
}

Department of Veterinary Public Health and Epidemiology, College of Veterinary Sciences, Lala Lajpat Rai University of Veterinary and Animal Sciences, Hisar-125004, Haryana, India

*Corresponding author

\begin{tabular}{|l|}
\hline Ke y w o r d s \\
$\begin{array}{l}\text { Infectious bursal } \\
\text { disease, Broiler } \\
\text { chickens, } \\
\text { Epidemiology }\end{array}$ \\
\hline Article Info \\
\hline $\begin{array}{l}\text { Accepted: } \\
\text { 06 May } 2018 \\
\text { Available Online: } \\
\text { 10 June } 2018\end{array}$ \\
\hline
\end{tabular}

\section{A B S T R A C T}

A retrospective study was conducted to understand the epidemiology of infectious bursal disease (IBD) in broiler chicken flocks in Haryana state. The epidemiological data related to IBD outbreaks for the period from January 2008 to June 2016 was analyzed. A total of 1368 outbreaks of IBD occurred during this period with overall morbidity, mortality and case fatality rate of $4.19 \%, 2.61 \%$ and $62.34 \%$ respectively. The disease was recorded throughout the year with maximum outbreaks in August month and in quarter July to September. Out of 1368 IBD outbreaks, maximum number of 734 (53.7\%) IBD outbreaks were reported in 21-30 days of age followed by 349 (25.5\%) in 11-20 days of age, 259 $(18.9 \%)$ in $31-40$ days of age and $26(1.9 \%)$ outbreaks in $41-50$ days of age. This indicates an increase in number of IBD outbreaks in 11-20 days of age cases as compared to earlier reports. Out of total IBD outbreaks, 918 were recorded in vaccinated flocks while 450 were in unvaccinated flocks. The case fatality rate was higher in unvaccinated flocks. Concurrent diseases were recorded in 627 IBD affected flocks. Pneumonia, coccidiosis, respiratory disease complex (RDC), E. coli infection, mycotoxicosis, Ranikhet disease and heat stroke were the major concurrent diseases. Improper immunization schedule, unhygienic conditions on the farm, emergence of newer strains of IBD virus, interference or absence of maternal antibodies could be the reasons for disease in vaccinated flocks. Continuous study may help in better understanding of infectious bursal disease in broiler chickens in this region.

\section{Introduction}

Infectious bursal disease (IBD) or Gumboro disease is an acute (Van den berg et al., 1991), highly contagious viral infection of poultry and causes heavy mortality and immunosuppression. It is caused by RNA virus of Avibirnavirus genus of Birnaviridae family (Dobos et al., 1979). After its first outbreak in poultry in Gumboro town in
Southern Delaware in the United States in 1957 (Cosgrove, 1962), the disease has been recorded from all over the world (Asrani et al., 1993, Muller et al., 2003). Between 1960 and 1964, the disease affected most regions of the USA (Lasher and Davis, 1997), and reached Europe in the years 1962 to 1971 (Faragher, 1972). From 1966 to 1974, the disease was identified in the Middle East, southern and western Africa, India, the Far East and 
Australia (Faragher, 1972; Firth, 1974; Jones, 1986; Van den Berg, 2000). IBD was first reported by Mohanty et al., (1971) from Uttar Pradesh in India.

The variant IBDV strains emerged in 1980's in IBDV-vaccinated farms in the Delmarva area and in the late 1980's, very virulent infectious bursal disease virus (vvIBDV) emerged in Europe (Chettle et al., 1989) which rapidly spread across continental Europe and Asia (Lin et al., 1993; Shcherbakova et al., 1998), Middle East (Pitcovski et al., 1998), South America (Difabio et al., 1999), and Africa (Zierenberg et al., 2000). However, there are significant differences between the African, European and Asian vvIBDV strains, suggesting independent evolution (Van den Berg, 2000). Based on a recent study, it is expected that, worldwide, about 60 to $76 \%$ of IBDV isolates are of vvIBDV genotype (Jackwood and Sommer, 2007; He et al., 2012). The strain variation seems to be one of reason for outbreaks of IBD even in the vaccinated flocks.

IBD has been reported in Assam (Sami and Baruah, 1997), Himachal Pradesh (Kurade et al., 2000), Tamil Nadu (Sivaseelan and Balachandran, 2003), Uttar Pradesh (Desingu et al., 2013) and in different parts of Haryana (Jindal et al., 2004; Mittal et al., 2005; Mor et al., 2010). Epidemiological study on the basis of data of poultry diseases from disease investigation laboratory Hisar, Haryana for the period July 1994 to June 2003 revealed that $8.89 \%$ flocks out of 795 poultry flocks were affected with vvIBDV (Jindal et al., 2004). Similar study for the period July 2005 to June 2008 revealed $4.54 \%$ morbidity with IBD in 483 poultry flocks of Haryana (Mor et al., 2010). Out of these 483 flocks, 334 flocks were vaccinated and 149 flocks were unvaccinated. We analyzed the epidemiological data of IBD outbreaks from
January 2008 to June 2016 in broiler chickens in parts of Haryana.

\section{Materials and Methods}

The epidemiological data of IBD in broiler chickens from January 2008 to June 2016 was collected from disease investigation laboratory of department of Veterinary Public Health and Epidemiology, Hisar. Live or dead birds are brought by the poultry farmers to laboratory for disease investigation on routine basis. Detailed information such as total birds in a flock, number of birds affected, number of birds died, age of affected birds, month of occurrence of disease, vaccination status and type of vaccines used was obtained from affected flocks. The disease was diagnosed in broiler chickens on the basis of clinical signs and pathognomic lesions as detailed in results and whenever required the representative samples were subjected to histopathological and PCR studies. Year wise distribution, temporal distribution, month wise, age wise and vaccination status were the criteria's used to analyse the IBD outbreaks. Data so collected was analyzed using Pearson Chi square test. Alpha was set at 95\%. Statistical software SPSSTM 20.0 (IBM, Corp. USA) was used.

\section{Results and Discussion}

\section{Occurrence of the disease}

Out of a total of 28044 disease outbreaks recorded during the period from January 2008 to June 2016, 1368 outbreaks (4.9\%) were of IBD. On analyzing the eight and a half year data, 98 IBD outbreaks were reported during the year 2008, 92 in 2009, 198 in 2010, 289 in 2011, 128 each in 2012 and 2013, 158 in 2014, 171 in 2015 and 106 outbreaks in 2016 up to the month of June (Table 1). The number of IBD outbreaks were highest in the year 2011 as compared to other years, however, the 
percent IBD outbreaks were highest in 2016 (7.1\%) and lowest in 2012 (3.2\%) (Fig. 1). During the period, the disease affected $3,93,257$ birds $(4.19 \%)$ out of 9383790 birds and caused mortality of 2,45,161 (2.61\%) broiler chicks.

On an average the case fatality rate (CFR) due to the IBD was $62.34 \%$. Pearson Chi square value was 16545.09 for morbidity, 10997.53 for mortality and 2389.36 for case fatality. Chi-square analysis showed that the prevalence of IBD significantly $(\mathrm{p}<0.05)$ varied over the years.

High case fatality rate reflects acute form of the disease in majority of the IBD-affected flocks. High case fatality rate and mortality may lead to considerable economic losses to the poultry farmers. In a previous study, Jindal et al., (2004) reported that IBD affected 8.89\% flocks during the nine year period with morbidity, cumulative mortality and case fatality rate of $5.9 \%, 3.63 \%$ and $61.43 \%$ respectively in Haryana state. Mittal et al., (2005) also recorded that IBD in broiler chicks accounted for $6.13 \%$ of outbreaks during the period from July, 2002 to June, 2003 in Haryana state. Mor et al., (2010) reported morbidity, cumulative mortality and case fatality rate of $4.54 \%, 2.34 \%$ and $51.69 \%$ respectively.

The results of the present study are in agreement with these reports. It appeared that over the years the occurrence of disease was increasing from 2008 to 2011 and came down in 2012 and again showed increasing trend till 2016. This is probably due to continuous strain variation in field virus as well as vaccination strategies adopted by the vaccine industry and farmers. The area of Haryana where this study was conducted is primarily a broiler chicken raising area. Such a study would provide a better picture about the epidemiology of IBD.

\section{Temporal distribution}

The whole year was divided into 4 quarters viz. Jan-March (A); April-June (B); July-Sept. (C); and Oct.-Dec. (D). The disease was recorded in all the quarters with maximum percent (7.50) of IBD outbreaks observed in quarter July-September (C) corresponding to rainy season. This was followed by quarter $\mathrm{D}$ $(4.96 \%), \mathrm{B}(4.08 \%)$ and quarter A $(3.81 \%)$ respectively in descending order. Percent morbidity varied from $3.74-5.02 \%$. It was significantly higher in quarter B than that in quarter C. Mortality rate varied from 2.38$3.09 \%$. The case fatality rate was higher in quarter $\mathrm{C}(63.75 \%)$ followed by quarter $\mathrm{D}$ (63.69\%), B (61.57\%) and A (60.36\%) (Fig.2). Pearson Chi square value was 5339.29 for morbidity, 2789.14 for mortality and 333.70 for case fatality in birds. Chi-square analysis showed that the prevalence of IBD significantly $(\mathrm{p}<0.05)$ varied over the different quarters (Table 2). These findings have the support of Choudhary et al., (2012) who reported that the incidence of IBD was higher among chickens during monsoon season $(36.73 \%)$ than the winter months $(30.83 \%)$ in and around the Ranchi, India. Rashid et al., (2013) also reported that higher mortality was observed in rainy season than other seasons.

Jindal et al., (2004), Mittal et al., (2005) and Mor et al., (2010) reported comparatively more outbreaks in winter season than in summer and rainy seasons in Haryana state. Though the occurrence of IBD in this study was more in July to September quarter (rainy season), percent morbidity and cumulative mortality were comparatively higher in April to June quarter (summer months). High mortality in summer season is expected because of high temperature stress. Immediately after rains, there is high humidity in the environment which may also substantially increase the mortality rate. 


\section{Month wise distribution}

Disease was present in all the months. Maximum number of IBD outbreaks were recorded in August month (175) followed by 136, 128, 125, 116, 111, 105, 104, 99, 98, 95, 76 in April, July, January, November, September, May, October, March, December, June and February respectively (Fig. 3). Percent morbidity varied from 3.28-7.81\% while percent mortality varied between 1.77 $3.2 \%$. Case fatality rate ranged from 55.21 to $69.21 \%$. Percent morbidity and mortality were highest in June month however the case fatality rate was highest in the month of July (Table 3).

\section{Effect of age}

The number of outbreaks in the age group of 21-30 days (53.7\%) was higher than in the age groups of 11-20 (25.5\%), 31-40 (18.9\%) and 41-50 days (1.9\%) (Fig.4). The morbidity rate due to the disease was $3.34 \%$ in chickens of age group 11-20 days, $4.63 \%$ in age group 2130 days, $4.34 \%$ in age group 31-40 days and $3.15 \%$ in age group 41-50 days. Percent mortality varied from $1.91 \%-2.98 \%$ and was highest in chickens of age group 21-30 days and lowest in the age group 11-20 days. The CFR was maximum (75.05\%) in birds of age group 41-50 days followed by $64.32 \%$, $60.70 \%$ and $57.12 \%$ in birds of age groups $21-$ $30,31-40$ and 11-20 days respectively (Table 4). It is interesting to note here that number of IBD outbreaks have increased in the age group of 11-20 days as compared to previous studies (10.2\% as reported by Mor et al., 2010) which is in contrast to general concept that birds are refractory to IBD for upto 3 weeks of age due to presence of maternal antibodies (MAbs). This could possibly be due to emergence of virulent strains of viruses (Sah et al., 1995). This may also be due to early age of vaccination of chicks in our area leading to neutralization of MAbs in some flocks as reported by some other workers (Tsukamoto $e t$ al., 1995; Alam et al., 2002; Hair-Bejo et al., 2004; Moraes et al., 2005) and may be due to absence of MAbs in some flocks making them susceptible to field virus. From our study, it appeared that the chicks of age 21-30 days were more susceptible to the disease with higher percent morbidity and mortality. Studies conducted in Ghana also revealed that $80 \%$ of the cases due to IBD occurred in the birds of age group 3-5 weeks (Anku, 2003). Mittal et al., (2005) reported that the disease was maximum in the age group of 21-30 days followed by 31-40 and 41-50 days in Haryana state. Zeleke et al., (2005) in Ethiopia reported that disease was affecting 20-45 days old broiler and layer chickens in the month of March and April. Mor et al., (2010) observed higher $(52.80 \%)$ occurrence of IBD in broiler chickens of 21-30 days of age and 10.2\% of cases in the age group of 11-20 day of age.

\section{Effect of vaccination}

To study the impact of vaccination on disease occurrence, the data was analyzed with regard to disease and vaccination status in flocks. 918 $(67.1 \%)$ of the disease outbreaks during the study period were in vaccinated flocks while the remaining $450 \quad(32.9 \%)$ were in unvaccinated flocks. Case fatality rate was comparatively more in unvaccinated flocks $(66.71 \%)$ than in vaccinated flocks $(61.01 \%)$. Commonly used vaccines against IBD were of Intermediate (I), intermediate plus $\left(\mathrm{I}^{+}\right)$, Georgia (G), MB strains. The vaccination was generally carried out in broiler chicks of 12-15 days of age through drinking water. The IBD outbreaks in vaccinated flocks have been reported by many workers (Mor et al., 2010; Choudhary et al., 2012; Adamu et al., 2013; Rashid et al., 2013; Owolodun et al., 2015, Morla et al., 2016; Patel et al., 2016). Mittal et al., (2005) also reported that more number $(80 \%)$ of outbreaks occurred in vaccinated flocks than the unvaccinated flocks. 
Table.1 Year-wise distribution of IBD in broiler chickens from January 2008 to June 2016

\begin{tabular}{|c|c|c|c|c|c|c|}
\hline Year & Total outbreaks & $\begin{array}{c}\text { No IBD outbreaks } \\
(\%)\end{array}$ & Flock size & $\begin{array}{c}\text { Morbidity } \\
(\%)\end{array}$ & $\begin{array}{c}\text { Mortality } \\
(\%)\end{array}$ & $\operatorname{CFR}^{1}(\%)$ \\
\hline 2008 & 2646 & $\begin{array}{c}98 \\
(3.7)\end{array}$ & 536150 & $\begin{array}{l}21316 \\
(3.98)\end{array}$ & $\begin{array}{l}15680 \\
(2.92)\end{array}$ & 73.56 \\
\hline 2009 & 2320 & $\begin{array}{c}92 \\
(4.0)\end{array}$ & 588300 & $\begin{array}{l}21283 \\
(3.62)\end{array}$ & $\begin{array}{l}13295 \\
(2.26)\end{array}$ & 62.47 \\
\hline 2010 & 3933 & $\begin{array}{c}198 \\
(5.0)\end{array}$ & 1014130 & $\begin{array}{l}37700 \\
(3.72)\end{array}$ & $\begin{array}{l}23450 \\
(2.31)\end{array}$ & 62.20 \\
\hline 2011 & 4796 & $\begin{array}{l}289 \\
(6.0)\end{array}$ & 1807820 & $\begin{array}{l}71153 \\
(3.94)\end{array}$ & $\begin{array}{l}45091 \\
(2.49)\end{array}$ & 63.37 \\
\hline $2012^{2}$ & 4063 & $\begin{array}{c}128 \\
(3.15)\end{array}$ & 858160 & $\begin{array}{l}22770 \\
(2.65)\end{array}$ & $\begin{array}{l}13276 \\
(1.55)\end{array}$ & 58.30 \\
\hline $2013^{*}$ & 3308 & $\begin{array}{c}128 \\
(3.87)\end{array}$ & 937630 & $\begin{array}{l}43630 \\
(4.65)\end{array}$ & $\begin{array}{l}27121 \\
(2.89)\end{array}$ & 62.16 \\
\hline 2014 & 2758 & $\begin{array}{c}158 \\
(5.73)\end{array}$ & 1241720 & $\begin{array}{l}47680 \\
(3.84)\end{array}$ & $\begin{array}{l}27314 \\
(2.20)\end{array}$ & 57.29 \\
\hline $2015^{*}$ & 2729 & $\begin{array}{c}171 \\
(6.27)\end{array}$ & 1380980 & $\begin{array}{l}79560 \\
(5.76)\end{array}$ & $\begin{array}{l}47853 \\
(3.47)\end{array}$ & 60.15 \\
\hline 2016 & 1491 & $\begin{array}{l}106 \\
(7.1)\end{array}$ & 1018900 & $\begin{array}{l}48165 \\
(4.73)\end{array}$ & $\begin{array}{l}32081 \\
(3.15)\end{array}$ & 66.61 \\
\hline Total & 28044 & $\begin{array}{l}1368 \\
(4.9)\end{array}$ & 9383790 & $\begin{array}{c}393257 \\
(4.19)\end{array}$ & $\begin{array}{c}245161 \\
(2.61)\end{array}$ & 62.34 \\
\hline
\end{tabular}

Table.2 Temporal distribution of IBD in broiler chickens from January 2008 to June 2016

\begin{tabular}{|c|c|c|c|c|c|c|}
\hline Quarters & $\begin{array}{c}\text { Total } \\
\text { outbreaks }\end{array}$ & $\begin{array}{c}\text { No. of IBD } \\
\text { outbreaks }(\%)\end{array}$ & Flock size & $\begin{array}{c}\text { Morbidity } \\
(\%)\end{array}$ & $\begin{array}{l}\text { Mortality } \\
(\%)\end{array}$ & $\operatorname{CFR}^{*}(\%)$ \\
\hline Jan.-March (A) & 7873 & $300(3.81)$ & 2227300 & $90012(4.04)$ & $54334(2.44)$ & 60.36 \\
\hline April-June (B) & 8236 & $336(4.08)$ & 2228530 & $111917(5.02)$ & 68909 (3.09) & 61.57 \\
\hline July-Sept. (C) & 5523 & $414(7.50)$ & 2627080 & $105243(4.01)$ & $67089(2.55)$ & 63.75 \\
\hline Oct.-Dec. (D) & 6412 & $318(4.96)$ & 2300880 & $86085(3.74)$ & $54829(2.38)$ & 63.69 \\
\hline Total & 28044 & $1368(4.88)$ & 9383790 & 393257 (4.19) & $245161(2.61)$ & 62.34 \\
\hline
\end{tabular}

${ }^{*}$ Case fatality rate

Table.3 Month-wise distribution of IBD in broiler chickens from January 2008 to June 2016

\begin{tabular}{|l|l|l|l|l|l|}
\hline Month & $\begin{array}{l}\text { No. of IBD } \\
\text { outbreaks }\end{array}$ & Flock size & Morbidity (\%) & Mortality (\%) & CFR (\%) \\
\hline January & 125 & 837250 & $31858(3.81)$ & $21724(2.59)$ & 68.19 \\
\hline February & 76 & 581450 & $23785(4.09)$ & $13636(2.35)$ & 57.33 \\
\hline March & 99 & 808600 & $34369(4.25)$ & $18974(2.35)$ & 55.21 \\
\hline April & 136 & 938850 & $28297(3.01)$ & $16652(1.77)$ & 58.85 \\
\hline May & 105 & 636930 & $32640(5.12)$ & $20362(3.20)$ & 62.38 \\
\hline June & 95 & 652750 & $50980(7.81)$ & $31895(4.89)$ & 62.56 \\
\hline July & 128 & 839740 & $34978(4.17)$ & $24208(2.88)$ & 69.21 \\
\hline August & 175 & 1086840 & $39038(3.59)$ & $24754(2.28)$ & 63.41 \\
\hline September & 111 & 700500 & $31227(4.46)$ & $18127(2.59)$ & 58.05 \\
\hline October & 104 & 802620 & $26335(3.28)$ & $17128(2.13)$ & 65.04 \\
\hline November & 116 & 756360 & $28765(3.80)$ & $17694(2.34)$ & 61.51 \\
\hline December & 98 & 741900 & $30985(4.18)$ & $20007(2.70)$ & 64.57 \\
\hline Total & $\mathbf{1 3 6 8}$ & $\mathbf{9 3 8 3 7 9 0}$ & $\mathbf{3 9 3 2 5 7}(\mathbf{4 . 1 9})$ & $\mathbf{2 4 5 1 6 1 ( 2 . 6 1 )}$ & $\mathbf{6 2 . 3 4}$ \\
\hline
\end{tabular}

*Case fatality rate 
Table.4 Distribution of IBD outbreaks in different age groups of broiler chickens

\begin{tabular}{|c|c|c|c|c|c|}
\hline $\begin{array}{l}\text { Age group } \\
\text { (days) }\end{array}$ & $\begin{array}{l}\text { No of IBD } \\
\text { outbreaks (\%) }\end{array}$ & Flock size & $\begin{array}{c}\text { Morbidity } \\
\text { (\%) }\end{array}$ & $\begin{array}{c}\text { Mortality } \\
(\%)\end{array}$ & $\begin{array}{l}\text { CFR } \\
(\%)\end{array}$ \\
\hline $11-20$ & $349(25.5)$ & 2639730 & $88115(3.34)$ & $50329(1.91)$ & 57.12 \\
\hline $21-30$ & 734 (53.7) & 5140370 & $238194(4.63)$ & $153201(2.98)$ & 64.32 \\
\hline $31-40$ & $259(18.9)$ & 1384250 & $60039(4.34)$ & $36446(2.63)$ & 60.70 \\
\hline $41-50$ & $26(1.9)$ & 219440 & $6909(3.15)$ & $5185(2.36)$ & 75.05 \\
\hline Total & 1368 & 9383790 & 393257 (4.19) & $245161(2.61)$ & 62.34 \\
\hline
\end{tabular}

Table.5 Effect of vaccination on occurrence of IBD in different age groups of broiler chickens

\begin{tabular}{|c|c|c|c|c|c|}
\hline $\begin{array}{c}\text { Age group } \\
\text { (days) }\end{array}$ & $\begin{array}{c}\text { No of IBD } \\
\text { outbreaks }(\%)\end{array}$ & $\begin{array}{c}\text { Flock } \\
\text { Size }\end{array}$ & $\begin{array}{c}\text { Morbidity } \\
(\%)\end{array}$ & $\begin{array}{c}\text { Mortality } \\
(\%)\end{array}$ & $\begin{array}{c}\text { CFR } \\
(\%)\end{array}$ \\
\hline $\mathbf{1 1 - 2 0}$ & $240(26.14)$ & 1847700 & $72060(3.90)$ & $39650(2.15)$ & 55.02 \\
\hline $\mathbf{2 1 - 3 0}$ & $477(51.96)$ & 3954470 & $193480(4.89)$ & $121890(3.08)$ & 63.00 \\
\hline $\mathbf{3 1 - 4 0}$ & $183(19.94)$ & 808400 & $32360(4.00)$ & $19740(2.44)$ & 61.00 \\
\hline $\mathbf{4 1 - 5 0}$ & $18(1.96)$ & 146800 & $3335(2.27)$ & $2490(1.70)$ & 74.66 \\
\hline Total & $\mathbf{9 1 8}$ & $\mathbf{6 7 5 7 3 7 0}$ & $\mathbf{3 0 1 2 3 5}(\mathbf{4 . 4 6})$ & $\mathbf{1 8 3 7 7 0}(\mathbf{2 . 7 2})$ & $\mathbf{6 1 . 0 1}$ \\
\hline & & & Unvaccinated Group & & \\
\hline $\mathbf{1 1 - 2 0}$ & $109(24.22)$ & 792030 & $16055(2.03)$ & $10679(1.35)$ & 66.52 \\
\hline $\mathbf{2 1 - 3 0}$ & $257(57.1)$ & 1185900 & $44714(3.77)$ & $31311(2.64)$ & 70.03 \\
\hline $\mathbf{3 1 - 4 0}$ & $76(16.88)$ & 575850 & $27679(4.81)$ & $16706(2.90)$ & 60.36 \\
\hline $\mathbf{4 1 - 5 0}$ & $8(1.88)$ & 72640 & $3574(4.92)$ & $2695(3.71)$ & 75.41 \\
\hline Total & $\mathbf{4 5 0}$ & $\mathbf{2 6 2 6 4 2 0}$ & $\mathbf{9 2 0 2 2}(\mathbf{3 . 5 0})$ & $\mathbf{6 1 3 9 1}(\mathbf{2 . 3 4})$ & $\mathbf{6 6 . 7 1}$ \\
\hline
\end{tabular}

Fig.1 Percent IBD outbreaks in broiler chickens from January 2008 to June 2016

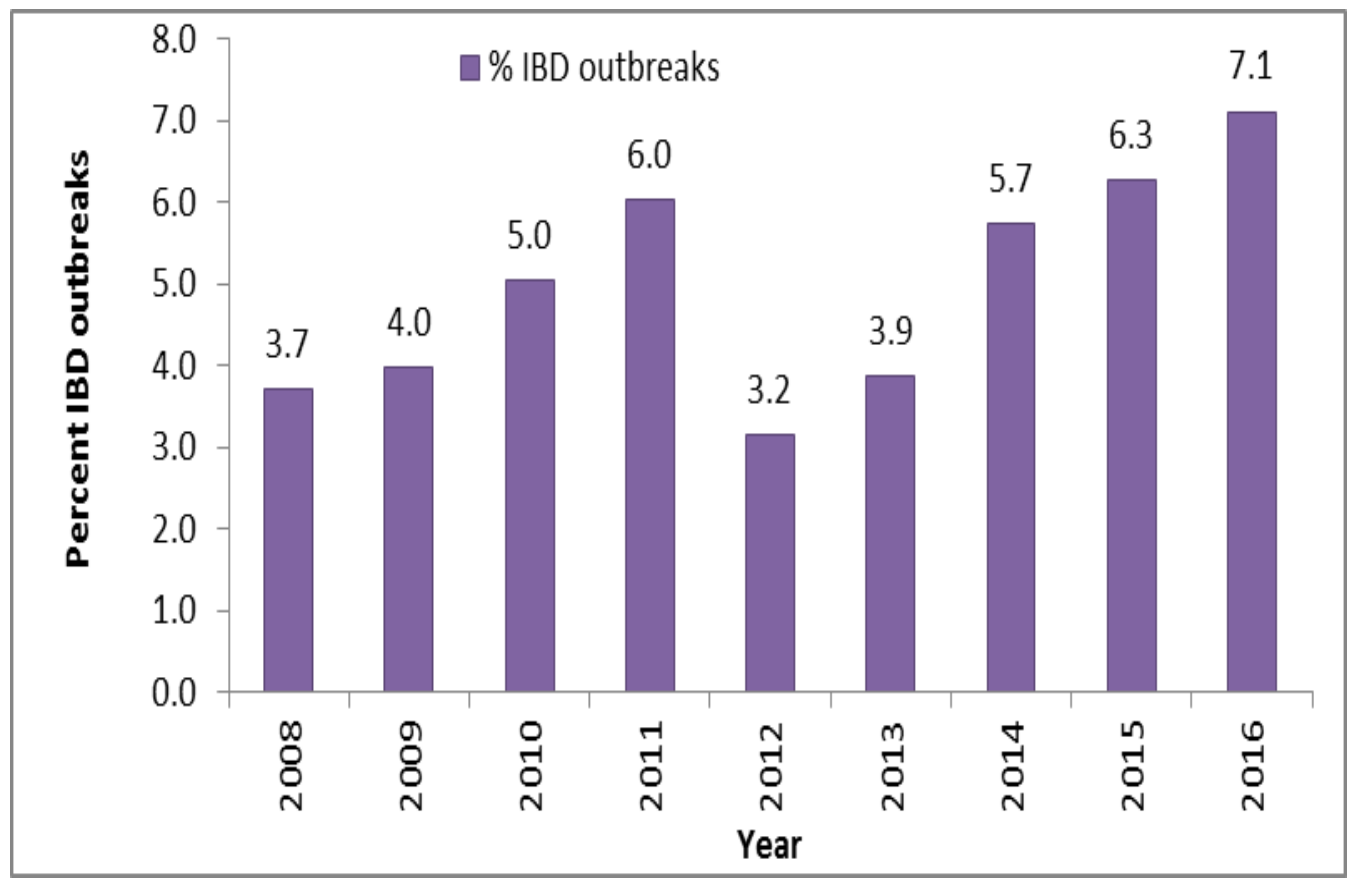


Fig. 2 Case fatality rate due to IBD in broiler chicken in different quarters from January 2008 to June 2016

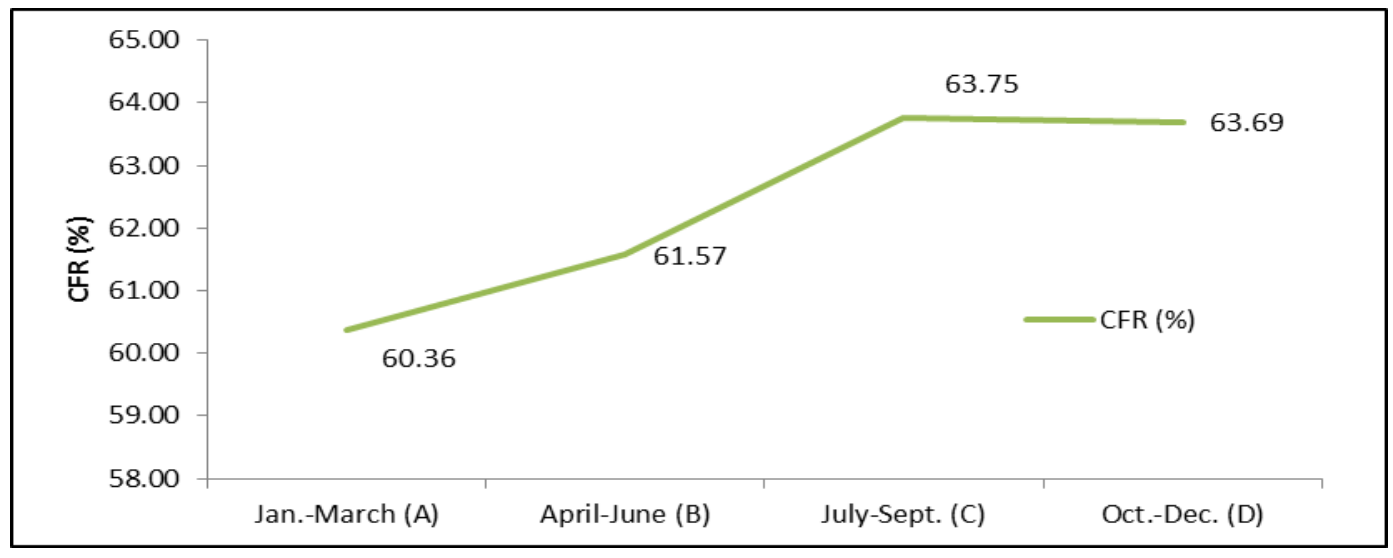

Fig.3 Month wise occurrence of IBD outbreaks in broiler chickens from January 2008 to June 2016

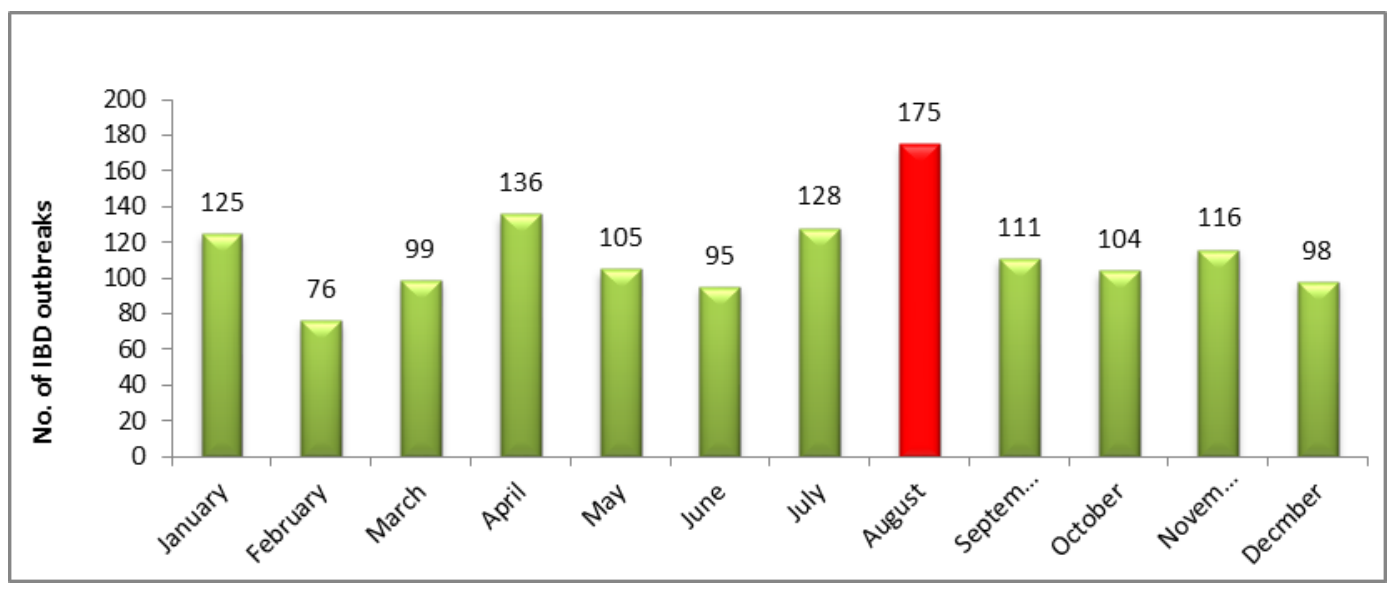

Fig.4 Bar diagram showing IBD outbreaks (\%) in different age groups of broiler chickens

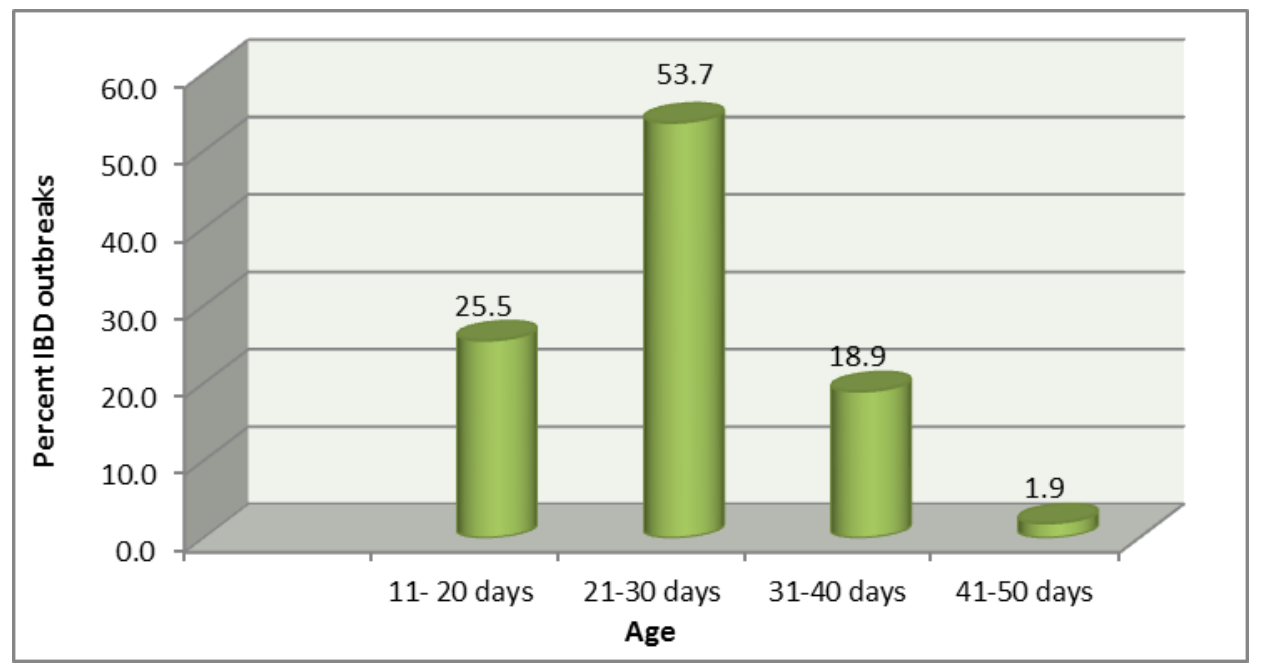


Fig.5 Photographs showing post-mortem lesions in infectious bursal disease affected broiler chickens

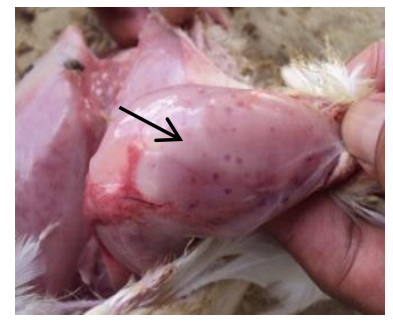

(a)

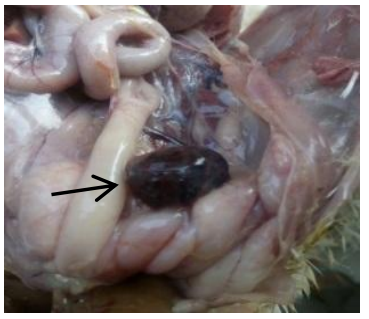

(b)

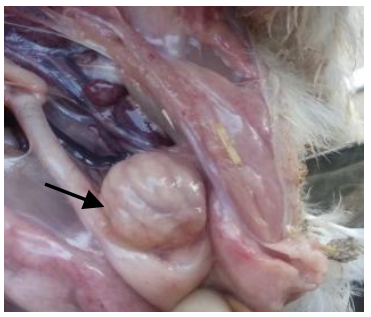

(c)

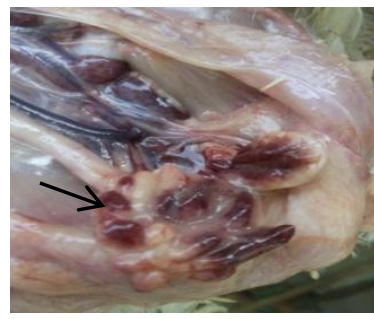

(d)

a) Haemorrhages on thigh muscles

b) Swollen, edematous and haemorrhagic bursa of Fabricius

c) Swollen, edematous bursa of Fabricius

d) Gelatinous exudates around bursa with haemorrhages in bursa

The IBD outbreaks in vaccinated flocks have also been recorded by Anku (2003) in Southern Ghana. Mor et al., (2010) observed that $69.15 \%$ of IBD affected flocks were vaccinated against this disease. Rashid et al., (2013) found that mortality due to IBD was significantly higher in unvaccinated birds as compared to vaccinated birds. Vaccine efficacy highly depends on the dose and strains of the vaccine and challenge viruses, as well as, the route of administration, the appropriate vaccination time, and the levels of maternal antibodies (OIE, 2012).

In Haryana, intermediate or intermediate plus vaccines (both live vaccines) of different manufacturers are generally used in broiler chicks and are administered through the drinking water. These vaccines though accord protection against IBD but are also immunosuppressive. A number of predisposing factors like overcrowding, poorly constructed brooder house and poor ventilation may be responsible for disease to occur in vaccinated flocks. Other factor could be the use of various strains of IBD vaccines that have failed to develop the desired immune response due to antigen variations within the causative agent. Poor vaccination practices, non-maintenance of cold chains during transport and at farm, use of chlorinated water for vaccine, exposing vaccine virus to outside environment for a longer duration, improper handling of vaccine, health status of flock, concurrent disease and low maternal antibody levels in day old chicks may also contribute to the occurrence of IBD even in vaccinated flocks. Most of the poultry farmers in this part of Haryana are not fully aware about proper handling of vaccines. If the vaccines is not properly handled and exposed to sunlight for a longer duration, the vaccination may not produce desired level of antibodies and such flocks though vaccinated will behave as unvaccinated flocks and would be prone to disease.

Concurrent infections were recorded in 627 flocks out of 1368 in the present study; pneumonia, coccidiosis, respiratory disease complex (RDC), E. coli infection, mycotoxicosis, Ranikhet disease and heat stroke were the major concurrent diseases observed. Khurshid et al., (1993) also reported secondary infections like coryza, colibacillosis and coccidiosis in broiler flocks affected with IBD. Anku (2003) reported that coccidiosis often accompanied the IBD outbreaks in Ghana. Mor et al., (2010) also reported concurrent infections with IBD. It is difficult to pin point whether IBD was a primary or secondary disease in flocks where there was concurrent infection. The diseases 
observed along with IBD are also capable to induce immunosuppression and predispose birds to IBD. Rashid et al., (2013) also observed mixed infection of New castle disease, Marek's disease, infectious bronchitis, salmonellosis, colibacillosis, aspergillosis along with IBD. Conversely, IBD may also induce immunosuppression and predispose birds in a flock to secondary complications. Further studies are required to determine whether these diseases are primary or secondary to IBD.

\section{Clinical findings}

The IBD affected birds brought to disease investigation laboratory, Hisar showed varied symptoms like dullness, depression, anorexia, ruffled feathers, diarrhoea, dehydration and inability to move. Feed intake of the affected birds was drastically reduced. Similarly, water intake was also affected. There was yellowish white or greenish yellow diarrhoea in most of the affected birds.

\section{Post-mortem findings}

In almost all IBD-affected birds, the postmortem lesions were observed in bursa of Fabricius. Haemorrhages on thigh and pectoral muscles (Fig. 5a), haemorrhages in bursal follicles (Fig. 5b), oedematous and swollen bursa (Fig. 5c), and presence of gelatinous exudates around bursa were recorded (Fig. 5d).

These changes were observed in acute form of the disease. However, in chronic form of the disease, the bursal changes comprised of atrophy and presence of cheesy core inside the bursa. The haemorrhages on thigh and pectoral muscles were of milder degree in sub-acute form of disease. In some of the flocks, haemorrhages at the junction of proventriculus and gizzard were also recorded.
From the present study, it can be concluded that outbreaks of IBD occur throughout the year in broiler chicken flocks in Haryana state even after vaccination. IBD showed increasing trend from 2012 to 2016. More IBD outbreaks were recorded in 11-20 and 21-30 days age groups. More IBD outbreaks were recorded in July- September quarter (rainy season).

\section{References}

Adamu, J., Owoade, A.A., Abdu, P.A., Kazeem, H.M. and Fatihu, M.Y. 2013. Characterization of field and vaccine infectious bursal disease viruses from Nigeria revealing possible virulence and regional markers in the VP2 minor hydrophilic peaks. Avian Pathol. 42(5): 420-433.

Alam, J., Rahman, M.M., Sil, B.K., Khan, M.S.R., Giasuddin and Sarker, M.S.K. 2002. Effect of maternally derived antibody on vaccination against infectious bursal disease (Gumboro) with live vaccine in broiler. Int. J. Poult. Sci. 1(4): $98-101$.

Anku, G.G., 2003. Gumboro hampers efforts to improve nutrition of Ghana's growing population. Poult. Int., 42: 32-35.

Asrani, R.K., Krishnaswamy, D., Narang, G., Kharole, M.U. and Krishnaswamy, S. 1993. Investigation on prevalence and immunological aspects of infectious bursal disease. In: Proceeding of $X^{\text {th }}$ World Veterinary Poultry Association Congress, Sydney (Australia). p. 159.

Chettle, N.J., Stuart, J.C. and Wyeth, P.J. 1989. Outbreaks of virulent infectious bursal disease in East Anglia. Vet. Rec., 125: 271-272.

Choudhary, U.K., Tiwary, B.K., Prasad, A. and Ganguly, S. 2012. Study on incidence of infectious bursal disease in and around Ranchi. Indian J. Anim. Res. 46(2): 156159. 
Cosgrove, A.S. 1962. An apparently new disease of chickens-avian nephrosis. Avian Dis. 6: 385-389.

Desingu, M.A., Barathidasan, R., Singh, S.D., Kumar, M., Palanivelu, M. and Dhama, K. 2013. Recurrent outbreaks of infectious bursal disease (IBD) in a layer farm caused by very virulent IBD virus (vvIBDV) in India: Pathology and molecular analysis. South Asian J. Exp. Biol. 3: 200- 206.

Difabio, J., Rossini, L.I., Eterradossi, N., Toquin, D. and Gardin, Y. 1999. European-like pathogenic infectious bursal disease viruses in Brazil. Veterinary Record 145: 203- 204.

Dobos, P., Hill, B.J., Hallett, R., Kells, D.T., Becht, H. and Teninges, D. 1979. Biophysical and biochemical characterization of five animal viruses with bisegmented double-stranded RNA genomes. J. Virol. 32: 593-605.

Faragher, J.T. 1972. Infectious bursal disease of chicken. Vet. Bull. 42: 361-369.

Firth, G.A. 1974. Occurrence of an infectious bursal syndrome within an Australian poultry flock. Aust. vet. J. 50: 128-130.

Hair-Bejo, M., Ng, M.K. and Ng, H.Y. 2004. Day-old vaccination against IBD in broiler chickens. Int. J. Poul. Sci. 3: 124128.

He, X., Wei, P., Yang, X., Guan, D., Wang, U.G. and Qin, A. 2012. Molecular epidemiology of infectious bursal disease viruses isolated from Southern China during the years 2000- 2010. Virus Gen. 45: $1-10$.

Jackwood, D.J. and Sommer-Wagner, S. 2007. Genetic characteristics of infectious bursal disease viruses from four continents. Virology 365(2), 369-375.

Jindal, N., Mahajan, N.K., Mittal, D., Gupta, S.L. and Khokhar, R.S. 2004. Some epidemiological studies on infectious bursal disease in broiler chickens in parts of Haryana, India. Int. J. Poult. Sci. 3(7): 478-482.
Jones B.A.H. 1986. Infectious bursal disease serology in New Zealand poultry flocks. N.Z. Vet.J. 34:36.

Khurshid, A., Najma, A., Monem, R.S., Ahmad, K., Arshad, N. and Rijvi, S.M. 1993. Incidence of infectious bursal disease (Gumboro) in broilers. Proc. Pakistan Congress Zoology. 13: 501-504.

Kurade, N.P., Bhat, T.K. and Jithendram, K.P. 2000. Occurrence of infectious bursal disease and its pathology in the birds of Himachal Pradesh. Indian J. Virol. 24: 133-134.

Lasher H.N. and Davis V.S. 1997. History of infectious bursal disease in the USA. The first two decades. Avian Dis. 41: 11-19.

Lin, Z., Kato, A., Otaki, Y., Nakamura, T., Sasmaz, E. and Ueda, S. 1993. Sequence comparisons of a highly virulent infectious bursal disease virus prevalent in Japan. Avian Dis. 37: 315-23.

Mittal, D., N. Jindal, S.L. Gupta, R.S. Kataria and A.K. Tiwari, 2005. Detection of infectious bursal disease virus in field outbreaks in broiler chickens by reverse transcription-polymerase chain reaction. Int. J. Poult. Sci. 4: 239-243.

Mohanty, G.C., Pandey, A.P. and Rajya, B.S. 1971. Infectious bursal disease in chicken. Curr. Sci. 40: 181-184.

Mor, S.K., Narang, G., Jindal, N., Mahajan, N.K., Sharma, P.C. and Rakha, N.K. 2010. Epidemiological studies on infectious bursal disease in broiler chickens in Haryana, India. Int. J. Poult. Sci. 9 (4): 395-400.

Moraes, H.L.D.S., Salle, C.T.P., Nascimento, V.P.D., Rocha, A.C.G.T. and Souza. G.F.D. 2005. Infectious bursal disease: Evaluation of maternal immunity and protection by vaccination of one-day old chicks against challenge with very virulent virus isolate. Brazi. J. Poult. Sci. 7: 51-57.

Morla, S., Deka, P. and Kumar, S. 2016. Isolation of novel variants of infectious bursal disease virus from different outbreaks in Northeast India. Microbiol. Pathogenesis. 93: 131-136. 
Muller, H., Islam, MR., Raue, R. 2003. Research on infectious bursal diseasethe past, the present and the future. Vet Microbiol 97: 153-165

OIE 2012. Office of International des Epizooties. Manual of Diagnostic Tests and Vaccines for Terrestrial Animals. Infectious Bursal Disease: Chap.2.3.12: 549-65.

Owolodun, O.A., Yakubu, B., Jambol, A.R., Audu, B.J., Dogonyaro, B.B. and Luka, P.D. 2015. Further evidence for very virulent infectious bursal disease virus in vaccinated chickens in Nigeria. Trop Anim. Hlth. Prod. 47: 1437-1441.

Patel, A.K., Pandey, V.C. and Pal, J.K. 2016. Evidence of genetic drift and reassortment in infectious bursal disease virus and emergence of outbreaks in poultry farms in India. Virus Dis. DOI 10.1007/s13337-016-0306-z.

Pitcovski, J., Goldberg, D., Levi, B.Z., DiCastro, D., Azriel, A., Krispel, S., Maray, T., and Shaaltiel, Y. 1998. Coding region of segment A sequence of a very virulent isolate of IBDV - comparison with isolates from different countries and virulence. Avian Dis. 42: 497-506.

Rashid, M.H., Xue, C., Islam, M.R., Islamc, M.T., and Cao, Y. A. 2013. Longitudinal study on the incidence of mortality of infectious diseases of commercial layer birds in Bangladesh. Prevent. Vet. Med. 109: 354-358.

Sah, R.L., Kataria, J.M., Arya, S.C. and Verma, K.C. 1995. Outbreak of acute infectious bursal disease causing high mortality in chicken. Indian J. Comp. Microbiol. Immunol. Infect. Dis. 16: 7-13.
Sami, W., and Baruah, G.K. 1997. Incidence of infectious bursal disease in broilers in Assam. Indian J. Vet. Pathol. 21: 67-68.

Shcherbakova, L.O., Lomakin, A.I., Borisov, A.V., Drygin, V.V. and Gusev, A.A. 1998. Comparative analysis of the VP2 variable region of the gene from infectious bursal disease virus isolates. Mol. Gen. Microbiol. Virusol. pp. 35-40.

Sivaseelan, S. and Balachandran, C. 2003. Pathology of naturally occurring infectious bursal disease in chicken. Cheiron. 32: 60-63.

Tsukamoto, K., Tanimura, N., Kakita, S.I., Ota, K., Mase, M., Imai, K. and Hihara, H. 1995. Efficacy of three live vaccines against highly virulent infectious bursal disease virus in chickens with or without maternal antibodies. Avian Dis. pp. 218229.

Van den Berg TP. 2000. Acute infectious bursal disease in poultry: a review. Avian Pathol. 29(1):175-194.

Van den Berg, T.P., Gonze, M. and Meulemans, G. 1991. Acute infectious bursal disease in poultry, isolation and characterisation of a highly virulent strain. Avian Pathol. 20: 133-143.

Zeleke, A., Gelaye, E., Sori, T., Ayelet, G., Sirak, A. and Zekarias, B. 2005 Investigation on Infectious Bursal Disease Outbreak in Debre Zeit, Ethiopia. International J. Poult. Sci. 4 (7): 504-506.

Zierenberg, K.., Nieper, H. Van den Berg, T.P. Ezeokoli, C.D. Voss, M. and Muller, H. 2000. The VP2 variable region of African and German isolates of infectious bursal disease virus: comparison with very virulent, "classical" virulent, and attenuated tissue culture-adapted strains. Arch. Virol. 145: 113-125.

\section{How to cite this article:}

Pooja Kundu, G. Narang, N.K. Mahajan, Priyanka Yadav and Jindal, N. 2018. Retrospective Study on Epidemiology of Infectious Bursal Disease in Broiler Chickens in Haryana, India. Int.J.Curr.Microbiol.App.Sci. 7(06): 1279-1290. doi: https://doi.org/10.20546/ijcmas.2018.706.150 